\title{
Modeling and Control of A Combined Wind-Solar Microgrid
}

\author{
Dan Shen, Afshin Izadian, Senior Member, IEEE \\ Energy Systems and Power Electronics Laboratory \\ Purdue School of Engineering and Technology, Indianapolis 46202, USA \\ aizadian@iupui.edu
}

\begin{abstract}
This paper introduces a standalone hybrid power generation system consisting of solar and wind power sources and a DC load. A supervisory control unit, designed to execute maximum power point tracking (MPPT), is introduced to maximize the simultaneous energy harvesting from overall power generation under different climatic conditions. Two contingencies are considered and categorized according to the power generation from each energy source, and the load requirement. Simulation results demonstrate effectiveness of the controllers and functionality of the maximum power point tracking algorithm in each operating condition for both solar and wind power sources.
\end{abstract}

\section{INTRODUCTION}

With the increasing demand of electricity and environmental issues of fossil fuels, alternative clean energies have attracted more attention. Compared with other renewables, wind and solar have been established as proven future sources of energy, because of their environment-friendly, safe, complimentary and cost-effective characteristics. However, there are some difficulties associated with combined utilization of solar and wind, such as their intermittent behavior and not matching generation and consumption peak hours. For this purpose, advanced network of multiple renewable energy systems with load or storage units have been proposed. Small-scale standalone combination of solar and wind has been found effective in some independent power supply system.

Many combined energy power systems by using various power electronic converters or control strategies have been put forward. Among them, [1] presents a neural network based control system to coordinate between the components of a PV-Wind hybrid system. [2] proposed a power control mechanism that can manage a combined photovoltaic (PV)/wind/fuel cell (FC) generation system including an ultra-capacitor bank. [3] introduced a novel strategy for the control of power conditioning units to minimize the disturbance on the output power from the hybrid system which integrated with PV and wind turbine. [4] introduced a holistic modeling method of a combined PV and wind power system. The goal of the work was to accomplish an optimized digital control followed by the rapid prototyping into a single Field Programmable Gate Array (FPGA) with Buck and Boost converter. [5] presents a new three-input dc-dc boost converter which is interesting for hybridizing alternative energy sources including PV source, fuel cell and battery. The control structure utilizes only four power switches that can accomplish tracking of the maximum power of PV and FC power, controlling the battery power and refining the output voltage with four different duty cycles. [6] recommended a novel adaptive strategy for power flow in standalone hybrid power system contains PV, battery and proton exchange membrane fuel cell. The method included a neural network controller in the first layer, a fuzzy logic controller in the second layer and local controllers which are used to regulate the set points in the third layer. [7] proposed the multiple-model adaptive estimation of a hydraulic wind power system. However, all of the mentioned methods which used conventional approaches or some advanced control techniques for controlling the combined generation system have proven to be unstable and have shown low reliability during the fast and nonlinear changes in weather conditions. Hence, simultaneous maximum power extraction from wind and solar has become a challenging research topic in the hybrid power systems.

This paper introduces a supervisory control system structure for a hybrid wind-solar-load power generation system. Maximum power is extracted from all sources by utilizing one layer DC-DC converters and an interface to the load. The cost effective MPPT and PI current controller are utilized to regulate the power flow to the load. All the control actions are determined by a supervisory controller.

\section{WIND MAXIMUM POWER POINT TRACKING}

Focusing on wind power system, various electric machines have been used as wind generators. A spectrum of these machines include permanent magnet (PM) brushless machines [8-10], doubly salient PM machines [11], induction machines [12] and switched reluctance machines [13-14]. These generators are designed to produce electric power and have to be controlled to maximize the output energy capture from wind turbines. MPPT methods have been proposed to improve wind system power production for both constant speed wind turbines and variable speed wind turbines. Although MPPT control methods are implemented using power electronics converters, generally these techniques can be classified into three main types: 1) power signal feedback (PSF) control, 2) tip-speed ratio (TSR) control, and 3 ) perturbation and observation $(\mathrm{P} \& \mathrm{O})$ control. PSF controller is mainly based on the maximum power characteristics curve resulting from simulation or field tests. The curve can be stored in form of lookup table in the controller. The controller is easy to implement for tracking of the best rotor speed to generate the corresponding power reference value without the need for wind speed measurement. Moreover, PSF is a stable approach as the data is interpolated from the data points available in the experimentally recorded lookup table. However, it is difficult to obtain the field data. The PSF control block diagram is shown in Figure 1.a [15-16].

The TSR control refines the rotational speed to keep the optimal tip-speed ratio for the maximum wind power utilization coefficient. The advantage of this method is the simple implementation approach. However, because of the 
requirement of wind information, the performance of TSR control approach relies on the anemometer accuracy or the estimated wind speed. Figure 1.b depicts the control block diagram of TSR [17].

The P\&O technique mainly generates a rotor speed perturbation and observes the variation of the output power to search for the point of maximum power. The advantage of the $\mathrm{P} \& \mathrm{O}$ method is that it requires neither wind turbine characteristics curve nor the generator parameters, so the control system can be used even under parameters changes. However, the P\&O method will lose its effectiveness in large-scale wind turbine systems because the generator power is largely influenced by the variation of turbine inertia. In addition, this method generates power generation oscillations that might become very large in higher power rating systems. Figure 1.c demonstrates the control block diagram of $\mathrm{P} \& \mathrm{O}$ method. As typical MPPT control methods are shown in Fig. 1, the $\mathrm{P} \& \mathrm{O}$ method can eliminate the measurement of wind speed so it is widely used for its ease of implementation [18-19].

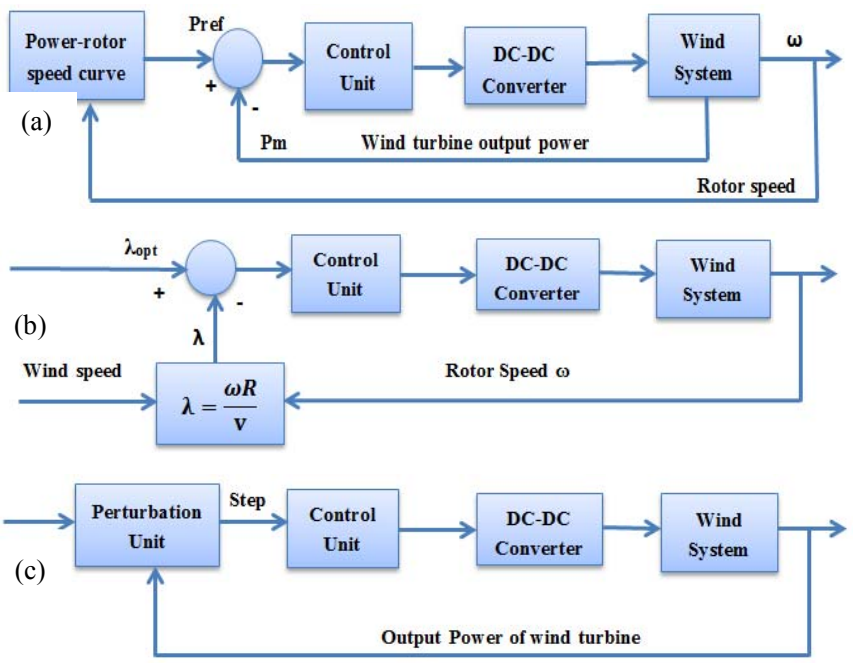

Fig. 1. Typical MPPT control for wind generation system. a) PSF, b) TSR, and c) $\mathrm{P} \& \mathrm{O}$.

\section{SOLAR MAXIMUM POWER POINT TRACKING}

A PV power system usually consists of solar panels, power converters and load. The maximum power point can be captured by tuning the controller and regulating the converter. Some MPPT control methods have also been proposed for PV generation system to eliminate the probable mismatch between load current and PV voltage and point of maximum power. In this way, tracking MPP is quite important for solar system not only to enhance the efficiency of system but also to reduce the cost of energy. These technologies include the fractional open-circuit voltage over short circuit current method, the incremental conductance (INC) method, the P\&O method, the power differential feedback control, the dc-link capacitor droop control and some other intelligent control methods. Among them, the P\&O method have also been widely adopted because of its simplicity and system independency [20-22].

\section{COMBINED SYSTEM DESCRIBTION}

The combined power system contains the wind power, the PV panel and the load. There are two main branches in the system, thus two new energy sources can compensate each other to some extent under climate changes. In practice, this kind of hybrid system is divided into two types: the stand alone off-grid system and the grid-connected system. The grid-connected system runs through an inverter that converts the current into AC electricity, unlike the off-grid systems the electricity produced by grid-connected system is fed into the grid. Fig. 2 depicts the configuration of the proposed hybrid new energy system[23-24].

The wind power system branch contains wind turbine, permanent magnet synchronous machine (PMSM), a universal bridge, SEPIC converter, wind MPPT controller and a local PI current controller. The PV power system branch is composed by PV panel, boost converter, solar MPPT controller and the local PI current controller. The perturb and observe MPPT algorithm is used in both PV system and wind system. Each source has its individual controller and a supervisory controller to coordinate and supervise the power flows among different power sources.

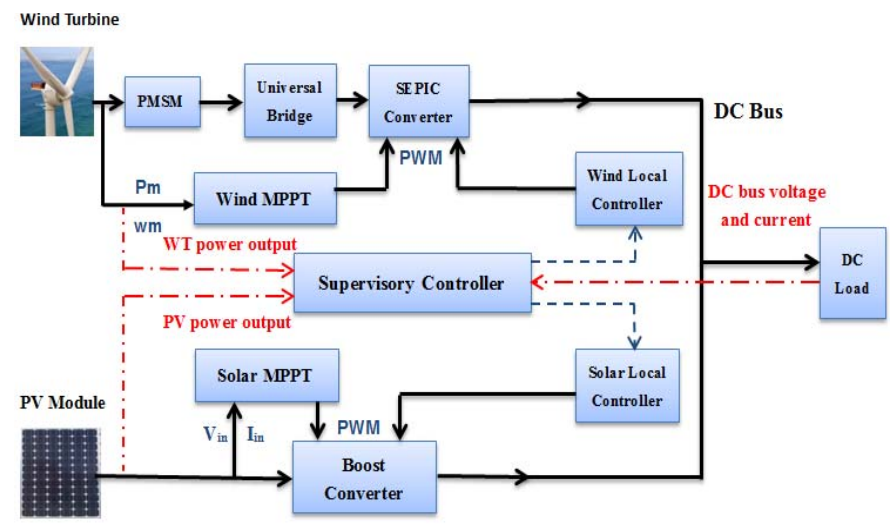

Fig. 2. Configuration of proposed hybrid new energy system

\section{SOLAR PHOTOVOLTAIC SYSTEM}

A PV module has been modeled in Matlab/Simulink. The simulation parameters setting of PV panel are listed in Table I.

TABLE I.

THE SIMULATION PARAMETERS SETTING OF PV PANEL

$\begin{array}{cccccccc}\boldsymbol{V}_{\boldsymbol{o c}} & \boldsymbol{I}_{\boldsymbol{s c}} & \boldsymbol{V}_{\boldsymbol{m}} & \boldsymbol{I}_{\boldsymbol{m}} & \boldsymbol{P}_{\boldsymbol{m}} & \boldsymbol{R}_{\boldsymbol{s}} & \boldsymbol{T}_{\boldsymbol{r e f}} & \boldsymbol{R}_{\boldsymbol{r e f}} \\ \mathbf{1 2 9 \mathrm { V }} & 19.2 \mathrm{~A} & 105.6 \mathrm{~V} & 17.1 \mathrm{~A} & 1800 \mathrm{~W} & 0.2 \Omega & 25^{\circ} \mathrm{C} & 1000 \mathrm{~W} / \mathrm{m}^{2}\end{array}$

In this table, $V_{o c}$ is the open circuit voltage, $I_{s c}$ is the short circuit current, $V_{m}$ and $I m$ are the nominal voltage and currents. $P_{m}$ in the nominal power, $R_{s}$ is the series resistance of the cell, Tref is the reference temperature and Rref is the radiation at the panel. Figures 3 and 4 show the $(I-V)$ and the $(P-V)$ curves of the PV model at different solar illumination intensity levels. 


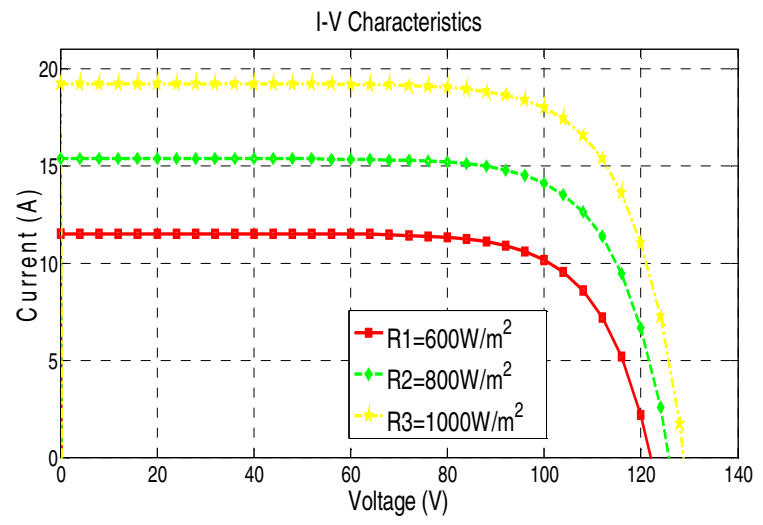

Fig. 3. I-V characteristics of PV model.

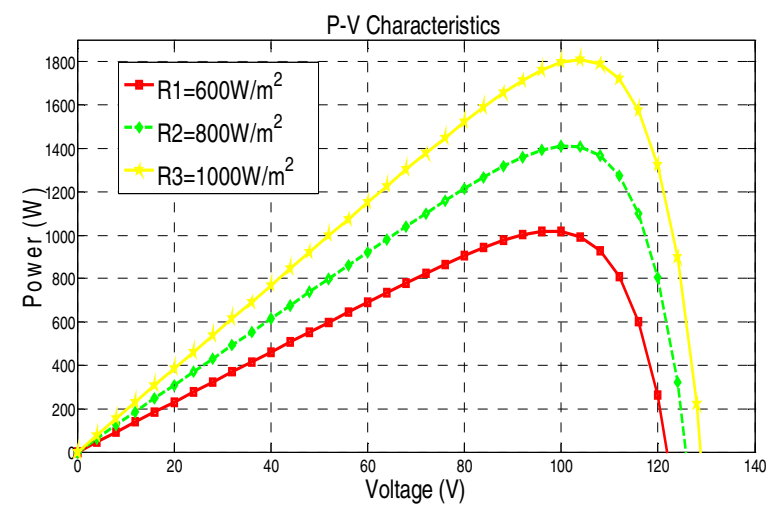

Fig. 4. P-V characteristics of PV model.

Fig. 3 and Fig. 4 show strong nonlinear relationship of I-V and P-V curve. The PV current decreases gradually when the $\mathrm{PV}$ voltage is low, as the voltage becomes lager than $\mathrm{V}_{\mathrm{m}}$ the PV current drops rapidly. The output power is the product of PV current and PV voltage and it has only one maximum power point under every specific solar radiation. Table II demonstrates the implementation of $\mathrm{P} \& \mathrm{O}$ method for solar system.

TABLE II

P\&O AlgORITHM IN SOLAR SYSTEM

\begin{tabular}{|c|c|c|}
\hline $\begin{array}{l}\text { Duty Cycle } \\
\text { Perturbation }\end{array}$ & $\begin{array}{c}\text { Change in } \\
\text { Power }\end{array}$ & $\begin{array}{l}\text { Duty Cycle } \\
\text { Next } \\
\text { Perturbation }\end{array}$ \\
\hline Positive & Increase & Positive \\
\hline Positive & Decrease & Negative \\
\hline Negative & Increase & Negative \\
\hline Negative & Decrease & Positive \\
\hline
\end{tabular}

Simulation of PV MPPT profile for a $30 \Omega$ load when the temperature is $25^{\circ} \mathrm{C}$ has been shown in Fig. 5. Fig. 5.a depicts the PV current $I_{p v}$ is around $I_{m}(17.1 \mathrm{~A})$. This shows the reach of maximum power point delivered from PV panel. Fig. 5.b illustrates the variation of perturbation signal during the irradiance changing from $600 \mathrm{~W} / \mathrm{m}^{2}$ to $1000 \mathrm{~W} / \mathrm{m}^{2}$ and then come back to $600 \mathrm{~W} / \mathrm{m}^{2}$, which oscillates slightly around the best duty ratio when the radiation changes quickly. As the figure shows, the maximum power points of PV model are approximately $1010 \mathrm{~W}, 1400 \mathrm{~W}$ and $1800 \mathrm{~W}$ when the solar radiances are $600 \mathrm{~W} / \mathrm{m}^{2}, 800 \mathrm{~W} / \mathrm{m}^{2}$ and $1000 \mathrm{~W} / \mathrm{m}^{2}$ respectively.

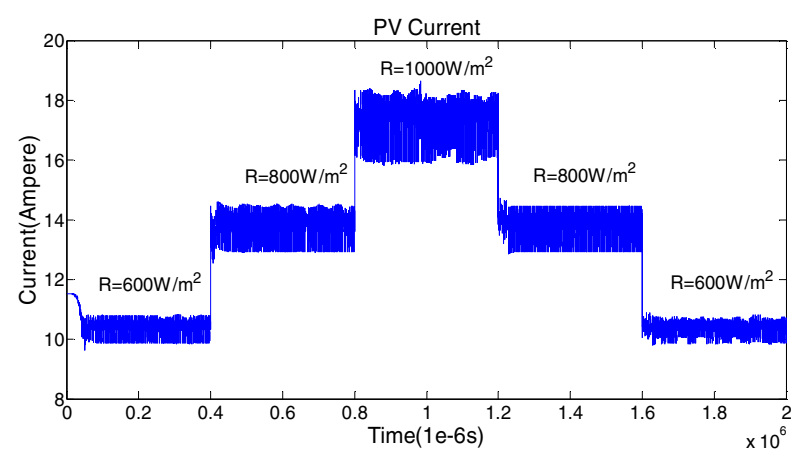

PV current

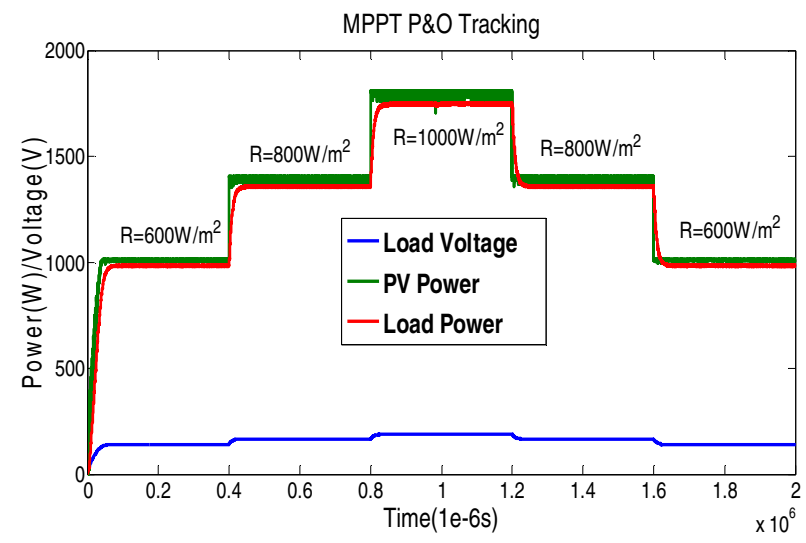

MPPT tracking effect

Fig. 5. PV MPPT Profile to step change in the irradiance from $600 \mathrm{w} / \mathrm{m} 2$ to $1000 \mathrm{~W} / \mathrm{m}^{2}$ to $600 \mathrm{~W} / \mathrm{m}^{2}$.

In order to evaluate the MPPT tracking efficiency for solar system, Table III demonstrates the power condition under different irradiance levels. From the table, the output power generated from PV cells, the load power and the power loss are calculated individually. The results show that the tracking efficiencies are more than $97 \%$ generally under the step change from $600 \mathrm{w} / \mathrm{m}^{2}$ to $1000 \mathrm{w} / \mathrm{m}^{2}$ to $600 \mathrm{~W} / \mathrm{m}^{2}$.

\section{TABLE III.}

Tracking EfFICIENCY In SOlar System

$\begin{array}{ccccc}\begin{array}{c}\text { Solar } \\ \text { Irradiance }\end{array} & \begin{array}{c}\text { PV } \\ \text { Power }\end{array} & \begin{array}{c}\text { Load } \\ \text { Power }\end{array} & \begin{array}{c}\text { Power } \\ \text { Loss }\end{array} & \begin{array}{c}\text { Tracking } \\ \text { Efficiency }\end{array} \\ \mathbf{6 0 0 W} / \mathbf{m}^{2} & 1000 \mathrm{~W} & 980 \mathrm{~W} & 20 \mathrm{~W} & 98.0 \% \\ \mathbf{8 0 0 W} / \mathbf{m}^{2} & 1400 \mathrm{~W} & 1360 \mathrm{~W} & 40 \mathrm{~W} & 97.1 \% \\ \mathbf{1 0 0 0} / \mathbf{m}^{2} & 1800 \mathrm{~W} & 1750 \mathrm{~W} & 50 \mathrm{~W} & 97.1 \%\end{array}$

\section{WIND ENERGY SYSTEM}

As part of the combined energy generation system, wind energy system is a device that can convert wind energy into electric energy. A typical wind generation system is composed of wind turbine and generator, the wind turbine converts wind energy into mechanical energy and then the generator converts the mechanical energy into electric energy. Fig. 6 illuminates the energy conversion chart of wind generation system. $P_{w}$ is the wind turbine input power; $C_{p}$ is wind power utilization coefficient, the theoretical maximum value of $C_{p}$ is 0.593 based on the Betz Theory. $\omega_{m}$ is rotor speed of the wind turbine, $\eta_{m}$ is the transmission efficiency which is over $95 \%, w_{t}$ is rotor speed 
of generator, $\eta_{g}$ is the efficiency of generator which is over $80 \%, P_{m}$ is the wind turbine mechanical output power, $P_{t}$ is transmission power, $P_{e}$ is output power of wind generator.

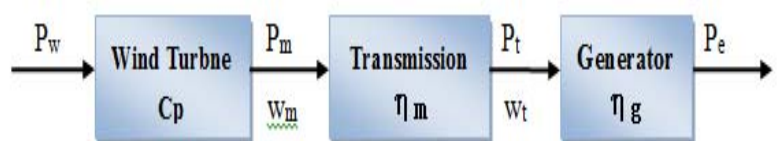

Fig. 6. Energy conversion chart of wind generation system

The foudamental equation of the relationship between wind turbine output power and wind speed is given by:

$$
\mathrm{P}=\frac{1}{2} p A V^{3} C_{p}
$$

where, $\rho$ is air density $\left(\mathrm{kg} / \mathrm{m}^{3}\right), \rho$ is $1.025 \mathrm{~kg} / \mathrm{m}^{3}$ in this paper. $A$ is area swept by rotor blads, $V$ is velocity of air $(\mathrm{m} / \mathrm{sec}), \mathrm{C}_{\mathrm{p}}$ is power coefficient of the wind turbine. The ratio of tip speed $\lambda$ and $C_{p}$ can be expressed as follows:

$$
\begin{aligned}
& \lambda=\frac{\omega R}{V}=\frac{2 \pi R n}{V}, \\
& C_{p}(\lambda, \beta)=c_{1}\left(\frac{c_{2}}{\lambda_{i}}-c_{3} \beta-c_{4}\right) e^{-\frac{c_{5}}{\lambda_{i}}}+c_{6} \lambda, \\
& \frac{1}{\lambda_{i}}=\frac{1}{\lambda+0.08 \beta}-\frac{0.035}{\beta^{3}+1} .
\end{aligned}
$$

In the above formula, $\omega$ is the rotor speed of wind turbine $(\mathrm{rad} / \mathrm{s}), \mathrm{n}$ is the rotational speed of wind turbine $(\mathrm{r} / \mathrm{s}), R$ is the radius of wind turbine ( $R=2.5 \mathrm{~m}$ in this paper), from the help information in Matlab [25-26], $C_{1}=0.5176, C_{2}=116, C_{3}=0.4$ , $C_{4}=5, C_{5}=21, C_{6}=0.0068$.

The proposed wind power system in this paper consists of a fixed pitch angle and variable speed wind turbine, a perpannent magnet generator (PMG) and a diode bdidge rectifier. The wind turbine and $\mathrm{PMG}$ connect directly without gearbox so the wind turbine torque and rotor speed are equal to the generator torque and rotor speed. Fig. 7 and Fig. 8 show the characteristics of the wind turbine power and torque vs. rotor speed.

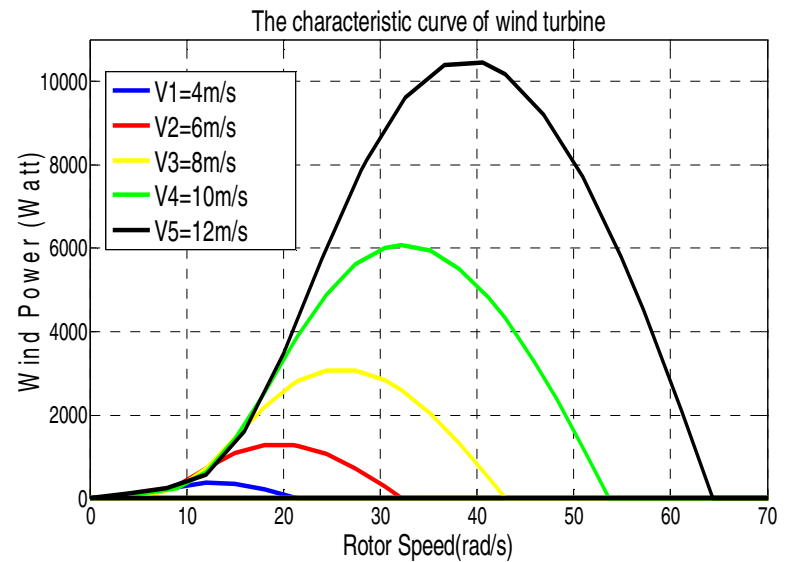

Fig. 7. Wind turbine power vs. rotor speed

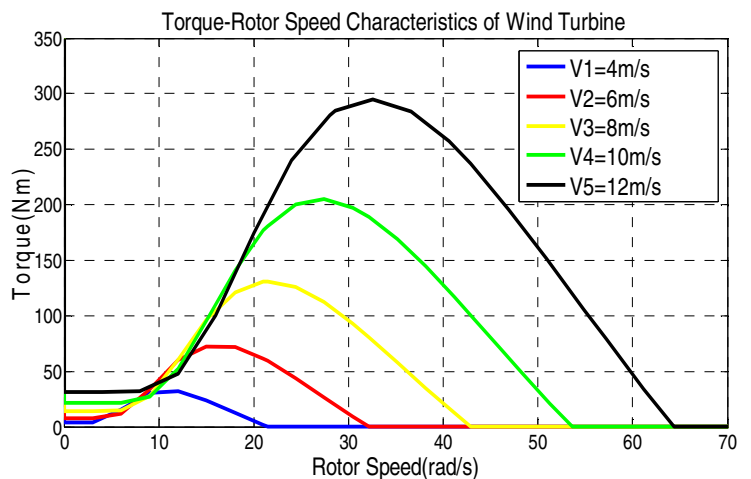

Fig. 8. Wind turbine torque vs. rotor speed

From Fig. 7 and Fig. 8, the maximum power under different wind speed is produced at different rotor speeds. Thus, the key point of tracking the MPP for wind turbine is to capture the optimal rotor speed for every wind speed. As mentioned above, many wind MPPT approaches have been proposed. In this paper the $\mathrm{P} \& \mathrm{O}$ method which is based on perturbing the turbine shaft speed with small steps and observing the resulting turbine output power changes is used. From (12) and (13), the wind turbine output power is,

$$
\begin{aligned}
& \mathrm{P}=\frac{1}{2} p A C_{p} \frac{\omega^{3} R^{3}}{\lambda^{3}}=K \omega^{3}, \\
& T=K \omega^{2},
\end{aligned}
$$

where $\mathrm{T}$ is wind turbine torque, $K=\frac{1}{2} p A C_{p} \frac{R^{3}}{\lambda^{3}}$. The $C_{p}-\lambda$ characteristics when the pitch angle is 0 degree is depicted in Fig. 9, so the maximum value of $C_{p \max }$ is 0.48 and the optimal $\lambda_{\text {opt }}$ is 8.1 .

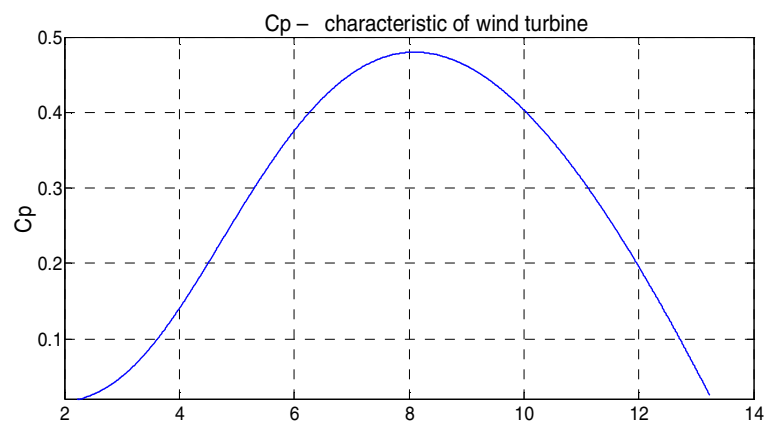

Fig. 9. $C p-\lambda$ characteristic of wind turbine $(\beta=0)$

In the proposed wind power system, the input power is constant when the wind speed is constant. Therefore, according to the principle of conservation of energy, if the output power can be increased, the energy consumed in the generator will be decreased and then the rotor speed of generator will be decreased. A SEPIC converter is employed to connect the wind turbine and load. With the increase of duty cycle, the output voltage increases and leads to the increment of output power; with the decrease of duty cycle, the output voltage decreases and leads to the decrement of output power. Thus, the P\&O method for wind MPPT can be accomplished by adjusting the duty cycle of SEPIC converter to change the rotor speed and keep the maximum $C_{p}$. Fig. 10 demonstrates the variation of rotor speed when tuning the duty cycle. Table IV lists the implementation of $\mathrm{P} \& \mathrm{O}$ method for wind system. 


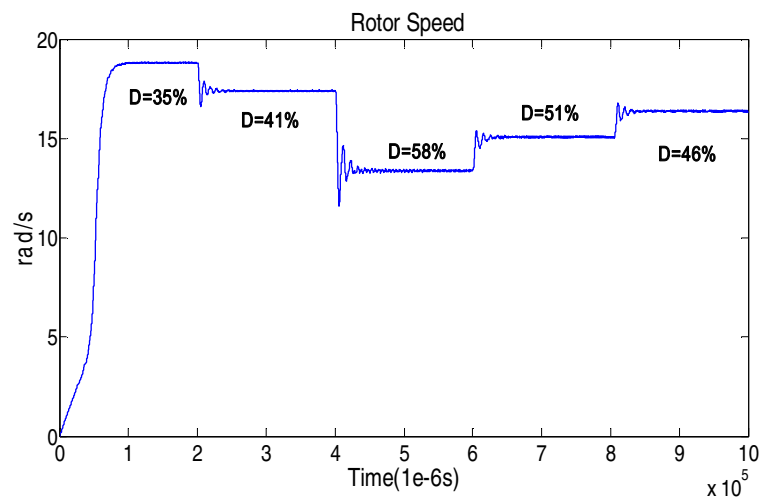

Fig. 10. Variation of rotor speed

TABLE IV.

P\&O ALgORITHM FOR WIND SYSTEM

$\begin{array}{cccc}\begin{array}{c}\text { Duty Cycle } \\ \text { Perturbation }\end{array} & \begin{array}{c}\text { Change in } \\ \text { Power }\end{array} & \begin{array}{c}\text { Change in } \\ \text { Rotor Speed }\end{array} & \begin{array}{c}\text { Duty Cycle } \\ \text { Next Perturbation }\end{array} \\ \text { Positive } & \text { Increase } & \text { Decrease } & \text { Positive } \\ \text { Positive } & \text { Decrease } & \text { Decrease } & \text { Negative } \\ \text { Negative } & \text { Increase } & \text { Increase } & \text { Negative } \\ \text { Negative } & \text { Decrease } & \text { Increase } & \text { Positive }\end{array}$

From the Table IV, the MPPT control for wind system can also be categorized into four circumstances:

1. $\mathrm{P}_{\mathrm{k}}>\mathrm{P}_{\mathrm{k}-1}$ and $\omega_{\mathrm{k}}>\omega_{\mathrm{k}-1}$, the output power at $\mathrm{k}$ moment is larger than that of k-1 moment, so the operating point is at the left side of MPP. $\omega_{\mathrm{k}}>\omega_{\mathrm{k}-1}$ means that the change in rotor speed increases, so the last duty cycle perturbation is negative. This causes that the next perturbation become negative;

2. $\mathrm{P}_{\mathrm{k}}<\mathrm{P}_{\mathrm{k}-1}$ and $\omega_{\mathrm{k}}<\omega_{\mathrm{k}-1}$, the output power at $\mathrm{k}$ moment is less than that of k-1 moment, so the operating point is at the left side of MPP. $\omega_{\mathrm{k}}<\omega_{\mathrm{k}-1}$ means that the change in rotor speed decreases, so the last duty cycle perturbation is positive. This causes that the next perturbation to become negative;

3. $\quad \mathrm{P}_{\mathrm{k}}>\mathrm{P}_{\mathrm{k}-1}$ and $\omega_{\mathrm{k}}<\omega_{\mathrm{k}-1}$, the output power at $\mathrm{k}$ moment is larger than that of k-1 moment, so the operating point is at the right side of MPP. $\omega_{k}<\omega_{k-1}$ means that the change in rotor speed decreases, so the last duty cycle perturbation is positive. This causes that the next perturbation become positive;

4. $\mathrm{P}_{\mathrm{k}}<\mathrm{P}_{\mathrm{k}-1}$ and $\omega_{\mathrm{k}}>\omega_{\mathrm{k}-1}$, the output power at $\mathrm{k}$ moment is less than that of k-1 moment, so the operating point is at the right side of MPP. $\omega_{k}>\omega_{k-1}$ means that the change in rotor speed increases, so the last duty cycle perturbation is nagative. This causes that the next perturbation to become positive.

Simulations of wind MPPT profile for a $30 \Omega$ load with wind speed variation from $4 \mathrm{~m} / \mathrm{s}$ to $12 \mathrm{~m} / \mathrm{s}$ are illustrated in Fig. 11 and Fig. 12. From the Fig.11(a) and Fig.12(a), the wind power utilization coefficient, it has been proven to reach Cpmax of 0.48 except in transient modes resulted by sudden wind speed changes. Fig.11(b) and Fig.12(b) depict the wind maximum power point tracking effects when the wind speed changed from $4 \mathrm{~m} / \mathrm{s}$ to $8 \mathrm{~m} / \mathrm{s}$ to $4 \mathrm{~m} / \mathrm{s}$, and $8 \mathrm{~m} / \mathrm{s}$ to $12 \mathrm{~m} / \mathrm{s}$ to $8 \mathrm{~m} / \mathrm{s}$ respectively. The figure also shows the output power generated directly from wind turbine and the actual power captured to the load.

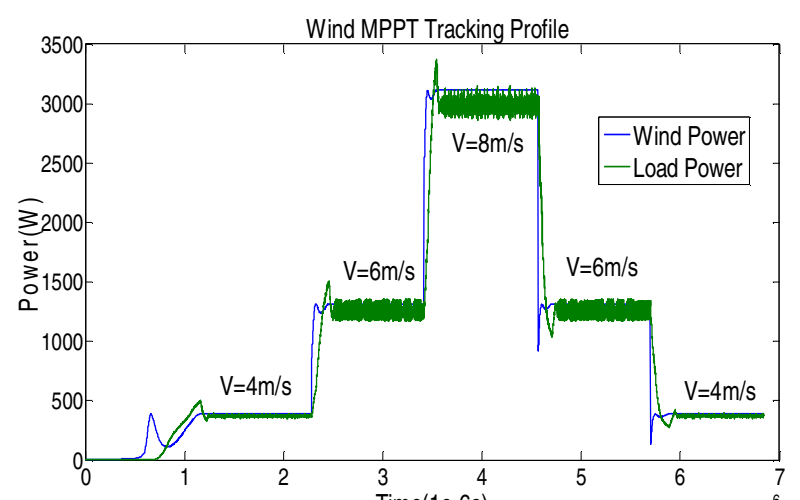

Fig. 11. Wind MPPT tracking profile to step change in the wind speed from $4 \mathrm{~m} / \mathrm{s}$ to $8 \mathrm{~m} / \mathrm{s}$ to $4 \mathrm{~m} / \mathrm{s}$

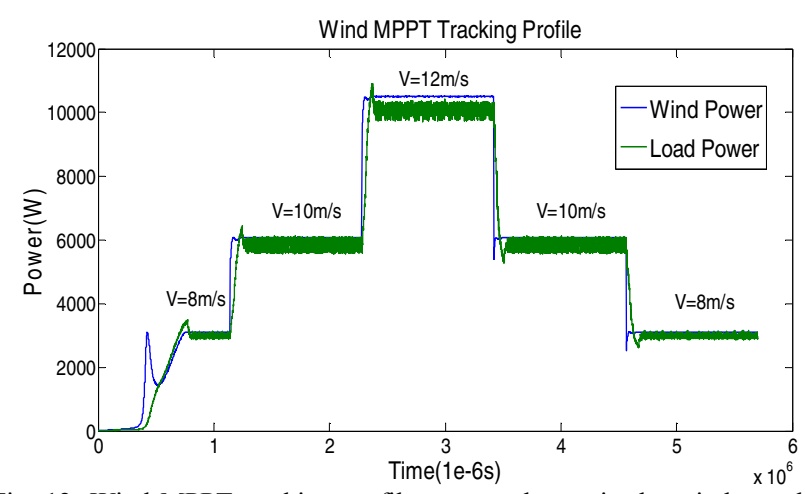

Fig. 12. Wind MPPT tracking profile to step change in the wind speed from $8 \mathrm{~m} / \mathrm{s}$ to $12 \mathrm{~m} / \mathrm{s}$ to $8 \mathrm{~m} / \mathrm{s}$

Similarly, the MPPT tracking efficiency has also been evaluated in the Table V. The table lists the wind power, load power and power loss to the step change of wind speed from $4 \mathrm{~m} / \mathrm{s}$ to $12 \mathrm{~m} / \mathrm{s}$. The calculation results show that the tracking efficiencies are all around $96 \%$ and that the intended target powers were achieved.

TABLE V.

MPPT TRACKING EFFICIENCY IN WIND SYSTEM

\begin{tabular}{ccccc}
$\begin{array}{c}\text { Wind } \\
\text { speed }\end{array}$ & Wind power & Load power & Power loss & $\begin{array}{c}\text { Tracking } \\
\text { efficiency }\end{array}$ \\
$\mathbf{4 m} / \mathbf{s}$ & $390 \mathrm{~W}$ & $370 \mathrm{~W}$ & $20 \mathrm{~W}$ & $94.9 \%$ \\
$\mathbf{6 m} / \mathbf{s}$ & $1310 \mathrm{~W}$ & $1260 \mathrm{~W}$ & $50 \mathrm{~W}$ & $96.2 \%$ \\
$\mathbf{8 m} / \mathbf{s}$ & $3110 \mathrm{~W}$ & $3000 \mathrm{~W}$ & $110 \mathrm{~W}$ & $96.8 \%$ \\
$\mathbf{1 0 m} / \mathbf{s}$ & $6080 \mathrm{~W}$ & $5850 \mathrm{~W}$ & $230 \mathrm{~W}$ & $96.2 \%$ \\
$\mathbf{1 2 m} / \mathbf{s}$ & $10500 \mathrm{~W}$ & $10050 \mathrm{~W}$ & $450 \mathrm{~W}$ & $95.7 \%$ \\
\hline
\end{tabular}

\section{SUPERVISORY CONTROL STRATEGY}

In a dc system fed by multiple converters on a common dc bus, power must be shared among the solar source and the wind source according to their available output power. Therefore, a supervisory controller is designed to track the maximum power generated from the two sources and manage the power to satisfy the load requirement. It is noted that this paper only considers obtaining the maximum power delivering to the load and not maintaining a constant power to the load. The dc bus voltage regulating and an energy storage charge or discharge procedure will be discussed in the future works. In 
order to accomplish the supervisory control strategy, the energy balance equation can be obtained as follows:

$$
\Delta P=P_{s}+P_{w}-P_{\text {Load }},
$$

where $\Delta P$ is the net power of the system, $P_{s}$ is the output power of solar, $P_{w}$ is the output power of wind, $P_{\text {Load }}$ is the power demand from load. The supervision modes can be clarified into two types (listed in Table VI). It can be categorized as follows:

- If $\triangle P \leq 0$, means that the power generation unit cannot satisfy the load. In this situation, both solar and wind power supplies must work in MPPT mode to generate the maximum power under different weather conditions to reduce the power shortage.

- If $\Delta P>0$, means that the power generation system can satisfy the load with surplus energy. In this situation, one source can be selected to operate in MPPT mode and the other source is set in power tracking mode by means of a PI current controller. The current reference value is determined as follows:

$$
I_{\text {ref }}=\frac{P_{\text {Load }}-P_{M P P T}}{V_{\text {Load }}}
$$

where $P_{M P P T}$ is the output power of the source which operates in MPPT mode, and $V_{\text {Load }}$ is the output voltage of load.

$$
\text { TABLE VI. }
$$

SUPERVISORY CONTROL CONTINGENCIES

$\begin{array}{ccc}\text { Mode } & \text { Condition } & \text { Control Action } \\ 1 & \Delta P \leqslant 0 & \text { Both in MPPT Control Mode } \\ 2 & \Delta P>0 & \text { Larger Power in MPPT Mode } \\ & & \text { Smaller Power in Power Tracking Mode }\end{array}$

The simulation results for a $30 \Omega$ load that demonstrate the supervisory control for the combined power system are depicted in Fig. 13-15 respectively. Fig. 13 demonstrates the load power reference value at 7HP and the irradiance is kept constant at $1000 \mathrm{~W} / \mathrm{m}^{2}$. The wind speed is changed from $6 \mathrm{~m} / \mathrm{s}$ to $8 \mathrm{~m} / \mathrm{s}$ to analyze the performance of the proposed supervisory control system. As $\Delta P$ is less than zero in the simulated wind speeds, both wind and solar power converters operate at MPPT mode. The supervisory controller successfully enabled the power generation unit to track the maximum power from both sources injected to a point of common coupling (PCC) i.e. the DC bus.

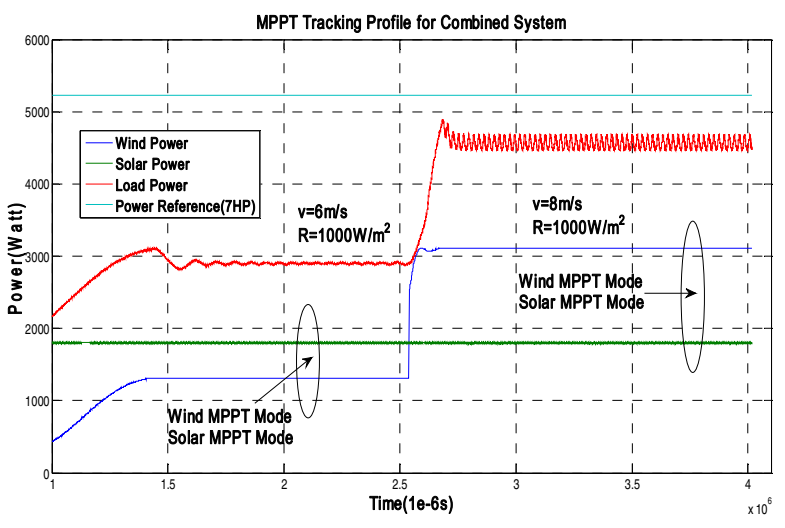

Fig. 13 MPPT Tracking profile for combined power generation unit under constant solar irradiance of $1000 \mathrm{~W} / \mathrm{m} 2$ and a step change in wind speed from $6 \mathrm{~m} / \mathrm{s}$ to $8 \mathrm{~m} / \mathrm{s}$

Fig. 14 illustrates a load reduction to 5HP under a constant wind speed at rate $8 \mathrm{~m} / \mathrm{s}$. In this case, the solar irradiance experienced a change from $400 \mathrm{~W} / \mathrm{m}^{2}$ to $1000 \mathrm{~W} / \mathrm{m}^{2}$. At $400 \mathrm{~W} / \mathrm{m}^{2}$, both sources operated at MPPT mode due to the $\triangle P<0$ condition. As the solar irradiation increased to $1000 \mathrm{~W} / \mathrm{m}^{2}, \Delta P>0$ was hold, suggesting excessive power generation than load demand and the wind power surpassed the solar power generation. Therefore, the wind source is controlled at MPPT mode and solar source is controlled at power tracking mode.

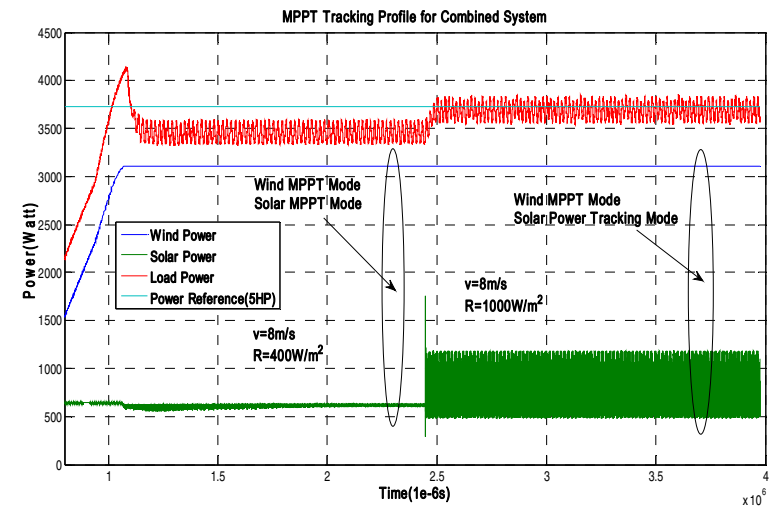

Fig. 14. MPPT Tracking profile for combined power system to constant wind speed $8 \mathrm{~m} / \mathrm{s}$ and step change in solar irradiance from $400 \mathrm{~W} / \mathrm{m} 2$ to $1000 \mathrm{~W} / \mathrm{m} 2$.

Fig. 15 depicts the MPPT tracking profile due to a step change in both wind speed and solar irradiance at a 5HP load power. Initially, the wind speed was $6 \mathrm{~m} / \mathrm{s}$ and the irradiance was $1000 \mathrm{~W} / \mathrm{m}^{2}$. A shortage of energy was observed $(\triangle P<0)$, hence both power sources operated at MPPT mode. Later a wind speed step change to $8 \mathrm{~m} / \mathrm{s}$ and irradiance decrease to $800 \mathrm{~W} / \mathrm{m}^{2}$ generated an excess of energy $(\triangle P>0)$. Larger power source was set to operate in MPPT mode and the solar power was set to operate in power tracking mode.

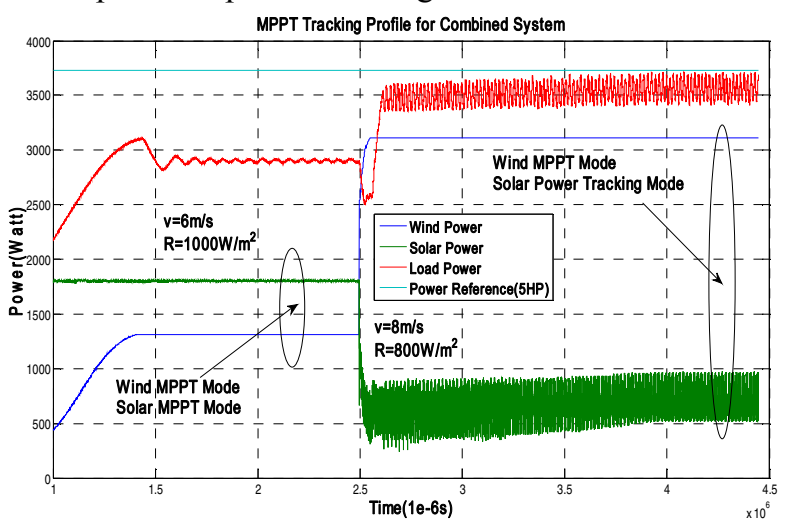

Fig. 15. MPPT Tracking profile for combined power system to step change in wind speed from $6 \mathrm{~m} / \mathrm{s}$ to $8 \mathrm{~m} / \mathrm{s}$ and step change in solar irradiance from $1000 \mathrm{~W} / \mathrm{m} 2$ to $800 \mathrm{~W} / \mathrm{m} 2$.

\section{CONCLUSION}

This work was focused on the modeling of wind turbine and solar panel and MPPT control methods for a combined wind system and solar power generation unit. Models of a 
horizontal axis wind turbine and a PV array, their MPPT and power tracking controllers were built in Matlab/Simulink. The P\&O method was utilized in both wind power and solar power, which demonstrated a stable and effective tracking performance under wind speed and solar irradiation changes. A supervisory control strategy was proposed to generate the maximum power from these renewable energy sources while connected to a point of common coupling PCC. A robust and smooth switching from MPPT to power tracking mode was obtained in both power sources. Simulation results demonstrated an accurate operation and applicability of the proposed method.

\section{REFERENCES}

[1] Fargli H M, Fahmy F H, EL-Sayed M A H. Artificial Intelligence Techniques for Controlling PV-Wind Powered Rural Zone in Egypt[C]//International Conference on Renewable Energies and Power Quality (ICREPQ'09). Valencia (Spain), 15th-17th April. 2009.

[2] Onar O C, Uzunoglu M, Alam M S. Modeling, control and simulation of an autonomous wind turbine/photovoltaic/fuel cell/ultra-capacitor hybrid power system, Journal of Power Sources, 2008, 185(2): 1273-1283.

[3] Wandhare R G, Agarwal V. A control strategy to reduce the effect of intermittent solar radiation and wind velocity in the hybrid photovoltaic/wind SCIG system without losing MPPT[C]/Photovoltaic Specialists Conference (PVSC), 2012 38th IEEE. IEEE, 2012: 001399-001404.

[4] Cirstea M, Parera-Ruiz A. An FPGA controller for a combined solar/wind power system[C]//Optimization of Electrical and Electronic Equipment (OPTIM), 2010 12th International Conference on. IEEE, 2010: 1103-1108.

[5] Nejabatkhah F, Danyali S, Hosseini S H, et al. Modeling and control of a new three-input DC-DC boost converter for hybrid $\mathrm{PV} / \mathrm{FC} /$ battery power system, . Power Electronics, IEEE Transactions on, 2012, 27(5): 2309-2324.

[6] Natsheh E M, Natsheh A R, Albarbar A. Intelligent controller for managing power flow within standalone hybrid power systems, . IET Science, Measurement \& Technology, 2013, 7(4) 191-200.

[7] M. Vaezi and A. Izadian, "Multiple-Model Adaptive Estimation of a Hydraulic Wind Power System," in Industrial Electronics Society, IECON 2013-39th Annual Conference of the IEEE, Vienna, Austria, 2013, pp. 2111-2116.

[8] Liu C, Chau K T, Zhang X. An efficient wind-photovoltaic hybrid generation system using doubly excited permanent-magnet brushless machine, Industrial Electronics, IEEE Transactions on, 2010, 57(3): 831-839.

[9] Niu S, Chau K T, Jiang J Z, et al. Design and control of a new double-stator cup-rotor permanent-magnet machine for wind power generation, Magnetics, IEEE Transactions on, 2007, 43(6): 2501-2503.

[10] Yu C, Chau K T, Jiang J Z. A flux-mnemonic permanent magnet brushless machine for wind power generation, Journal of Applied Physics, 2009, 105(7): 07F114.
[11] Y. Fan, K. T. Chau, and M. Cheng, "A new three-phase doubly salient permanent magnet machine for wind power generation," IEEE Trans. Ind.Appl., vol. 42, no. 1, pp. 53-60, Jan./Feb. 2006.

[12] Cimuca G O, Saudemont C, Robyns B, et al. Control and performance evaluation of a flywheel energy-storage system associated to a variable-speed wind generator, Industrial Electronics, IEEE Transactions on, 2006, 53(4): 1074-1085.

[13] Torrey D A. Switched reluctance generators and their control, Industrial Electronics, IEEE Transactions on, 2002, 49(1): 3-14.

[14] Ermis M, Ertan H B, Akpinar E, et al. Autonomous wind energy conversion system with a simple controller for maximum-power transfer, Electric power applications, IEE Proceedings B, 1992, 139(5): 421-428.

[15] Barakati S M, Kazerani M, Aplevich J D. Maximum power tracking control for a wind turbine system including a matrix converter, Energy Conversion, IEEE Transactions on, 2009, 24(3): 705-713.

[16] Cardenas R, Pena R. Sensorless vector control of induction machines for variable-speed wind energy applications, Energy Conversion, IEEE Transactions on, 2004, 19(1): 196-205.

[17] Abo-Khalil A G, Lee D C. MPPT control of wind generation systems based on estimated wind speed using SVR, Industrial Electronics, IEEE Transactions on, 2008, 55(3): 1489-1490.

[18] Koutroulis E, Kalaitzakis K. Design of a maximum power tracking system for wind-energy-conversion applications, Industrial Electronics, IEEE Transactions on, 2006, 53(2): 486-494.

[19] Yu C, Chau K T. Thermoelectric automotive waste heat energy recovery using maximum power point tracking, Energy Conversion and Management, 2009, 50(6): 1506-1512.

[20] Gules R, De Pellegrin Pacheco J, Hey H L, et al. A maximum power point tracking system with parallel connection for PV stand-alone applications, Industrial Electronics, IEEE Transactions on, 2008, 55(7): 2674-2683.

[21] Femia N, Lisi G, Petrone G, et al. Distributed maximum power point tracking of photovoltaic arrays: Novel approach and system analysis, . Industrial Electronics, IEEE Transactions on, 2008, 55(7): 2610-2621.

[22] Patel H, Agarwal V. Maximum power point tracking scheme for PV systems operating under partially shaded conditions, Industrial Electronics, IEEE Transactions on, 2008, 55(4): 1689-1698.

[23] Wang F, Wu X, Lee F C, et al. Analysis of unified output MPPT control in Sub-Panel PV converter system[C]/Power Electronics and Applications (EPE), 2013 15th European Conference on. IEEE, 2013: 1-8.

[24] Bahas P. The Arizona University photovoltaic designer program (ASUPVD), 1996.

[25] Patel M R. Wind and solar power systems: design, analysis, and operation [M]. CRC press, 2012.

[26] Mesemanolis A, Mademlis C. A Neural Network Based MPPT Controller for Variable Speed Wind Energy Conversion Systems, 2012. 